\title{
STRATEGI PEMASARAN PRODUK PEPSODENT DALAM MENINGKATKAN VOLUME PENJUALAN PT. UNILEVER Tbk. AREA BANDAR LAMPUNG
}

\author{
Pepsodent Marketing Strategy in Increasing Sales Volume of \\ PT. Unilever Tbk. Bandar Lampung Area
}

\author{
Melan Susanty Purnamasari ${ }^{1}$, Aslami Lazuardi Fartana ${ }^{2}$ dan Erfina ${ }^{3}$ \\ Program Studi Administrasi Bisnis FISIP Universitas Tulang Bawang Lampung \\ melan.susanty@utb.ac.id
}

\begin{abstract}
Pepsodent toothpaste products attract consumers from the physical side and benefits so that consumers get information from Pepsodent toothpaste products for consideration in purchasing decisions. Therefore, companies need to study and know consumer or community responses to Pepsodent toothpaste, factors that can fulfill consumer desires and how far the position of this product is in the minds of consumers.This study analyzes how the marketing strategy of Pepsodent toothpaste products in increasing the sales volume of PT. Unilever Tbk. Bandar Lampung area. The purpose of this study is to find out what strategies can be done to increase the sales volume of PT. Unilever Tbk. Bandar Lampung area with a descriptive-qualitative research method, the key informant in this study was a branch manager of PT. Unilever Tbk. Bandar Lampung area, agent and marketing of Pepsodent products PT. Unilever Tbk. Bandar Lampung area, while the informants in this study were regular consumers of Pepsodent Toothpaste products in Bandar Lampung.
\end{abstract}

Keywords: marketing strategy, sales volume, product

\begin{abstract}
ABSTRAK
Produk pasta gigi Pepsodent menarik konsumen dari sisi fisik dan manfaat sehingga konsumen mendapatkan informasi dari produk pasta gigi Pepsodent untuk bahan pertimbangan dalam keputusan pembelian. Oleh sebab itu, perusahaan perlu mempelajari dan mengetahui tanggapan konsumen atau masyarakat dengan adanya pasta gigi Pepsodent, faktor yang dapat memenuhi keinginan konsumen dan seberapa jauh posisi produk ini di dalam benak konsumen.

Penelitian ini menganalisis tentang Bagaimana strategi pemasaran produk pasta gigi Pepsodent dalam meningkatkan volume penjualan PT. Unilever Tbk. area Bandar Lampung. Tujuan penelitian ini yaitu untuk mengetahui strategi apa yang dapat dilakukan untuk meningkatkan volume penjualan PT. Unilever Tbk. area Bandar Lampung dengan metode penelitian secara deskriptif-kualitatif, key informan dalam penelitian ini adalah seorang pimpinan cabang PT. Unilever Tbk. Area Bandar Lampung, Agen dan marketing produk pepsodent PT. Unilever Tbk. Area Bandar Lampung, sedangkan informan dalam penelitian ini adalah konsumen tetap produk Pasta Gigi Pepsodent di Bandar Lampung.
\end{abstract}

Kata kunci: strategi pemasaran, volume penjualan, produk

\section{PENDAHULUAN}

Dewasa ini perkembangan dunia usaha maju dengan pesat, hal ini ditandai dengan tingkat persaingan yang semakin ketat. Oleh karena itu bagi perusahaan yang mempunyai keinginan 
untuk memenangkan persaingan tersebut harus mampu merebut konsumen. Dalam merebut konsumen diperlukan suatu strategi pemasaran yang tepat. Sebelum menentukan stategi hendaknya perusahaan mengidentifikasikan keinginan konsumen yang belum dipuaskan, dengan cara menentukan barang yang hendak diproduksi, menentukan cara promosi, menentukan harga yang tepat, dan memilih saluran distribusinya. Jadi kegiatan pemasaran merupakan suatu proses yang saling berhubungan sebagai suatu sistem.

Konsumen membeli barang dan jasa adalah untuk memuaskan berbagai keinginannya, oleh karena itu penting bagi perusahaan untuk mempelajari bagaimana perilaku konsumen tersebut dalam pengambilan keputusan belinya. Keinginan manusia yang beraneka ragam, akan menimbulkan berbagai macam perilaku untuk memenuhinya.

Manusia dalam kehidupan sehariharinya harus selalu memenuhi keperluannya untuk hidup sehat. Salah satunya adalah mengenai kesehatan dan kebersihan gigi. Seseorang yang giginya bersih akan berpenampilan lebih menarik dan timbul rasa percaya diri pada saat berbaur dengan orang lain. Dalam keperluan untuk menjaga kesehatan gigi diperlukan berbagai macam produk kesehatan antara lain sikat gigi, obat kumur dan pasta gigi. Adapun dalam penyusunan penelitian ini, masalah yang akan dibahas adalah mengenai pasta gigi.

Dari banyaknya merk pasta gigi yang beredar di masyarakat yang berkeinginan untuk dibeli antara lain Close up, Ciptadent, Formula, Siwak F, Enzim, Ritadent, dan Pepsodent. Dari sekian banyaknya merk pasta gigi tersebut di atas, salah satu merk pasta gigi yang akan diteliti adalah pasta gigi Pepsodent.

\section{TINJAUAN PUSTAKA}

Menurut Stephanie K. Marrus (2002), Strategi didefinisikan sebagai suatu proses penentuan rencana para pemimpin puncak yang berfokus pada tujuan jangka panjang organisasi, disertai penyusunan suatu cara atau upaya bagaimana agar tujuan tersebut dapat dicapai.

Pemasaran telah didefinisikan dalam berbagai pengertian seperti menurut American Marketing Association adalah proses penyusunan komunikasi terpadu yang bertujuan untuk memberikan informasi mengenai barang atau jasa dalam kaitannya dengan memuaskan kebutuhan dan keinginan manusia. Pemasaran dimulai dengan pemenuhan kebutuhan manusia yang kemudian bertumbuh menjadi keinginan manusia. (Manajemen Pemasaran-Prof. DR. Sofjan Assauri, M.B.A).

Dilihat dari asal usul kata (etimologi), istilah pemasaran yang dalam bahasa Inggrisnya "marketing”. Kata marketing ini boleh dikatakan sudah diresap dalam bahasa kita, namun juga diterjemahkan dengan istilah pemasaran. Asal kata pemasaran adalah pasar $=$ market. Karena itulah dalam kehidupan seharihari istilah marketing sering disamakan dengan pemasaran (Alma, 2013).

Menurut Kotler, pengertian pemasaran adalah aktivitas sosial dan sebuah pengaturan yang dilakukan oleh perorangan ataupun sebuah kelompok orang dengan tujuan untuk mendapatkan tujuan mereka dengan jalan membuat produk dan menukarkannya dengan besaran nominal tertentu ke pihak lain.

Strategi Pemasaran merupakan hal yang sangat penting bagi perusahaan dimana strategi pemasaran merupakan satu cara mencapai tujuan dari sebuah perusahaan. Hal ini juga didukung oleh 
pendapat Swastha "Strategi adalah serangkaian rancangan besar yang menggambarkan bagaimana sebuah perusahaan harus beroperasi untuk mencapai tujuannya, sehingga dalam menjalankan usaha kecil khususnya diperlukan adanya pengembangan melalui strategi pemasarannya". Karena pada kondisi kritis justru usaha kecillah yang mampu memberikan pertumbuhan terhadap pendapatan masyarakat.

Pengertian Bauran Pemasaran (Marketing Mix) adalah "Marketing mix is the set of marketing tools that the firm uses to pursue it's marketing objectives in the market."(Marketing Management, 2012) yang kurang lebih memiliki arti bauran pemasaran adalah kumpulan dari variabel-variabel pemasaran yang dapat dikendalikan yang digunakan oleh suatu badan usaha untuk mencapai tujuan pemasaran dalam pasar sasaran.

Menurut Kotler and Keller (2016), Marketing mix is the set of marketing tools that the firm uses to pursue its marketing objectives in the target market yang kurang lebih memiliki arti bahwa bauran pemasaran adalah sejumlah alat-alat pemasaran yang digunakan perusahaan untuk menyakinkan obyek pemasaran atau target pasar yang dituju.

Menurut Stanton (2012) Bauran pemasaran (marketing mix) adalah kombinasi dari 4 variabel atau kegiatan yang merupakan inti dari sistem pemasaran perusahaan yaitu produk, harga, kegiatan promosi dan sistem distribusi.

Ada banyak alat pemasaran, Mc.Carthy (2009) mempopulerkan pembagian kiat pemasaran ke dalam 4 (empat) faktor yang disebut the four $P$ : product, price, place, and promotion" (Kotler and Armstrong, 2012).

Keempat bauran pemasaran tersebut secara singkat dijelaskan sebagai berikut:
1. Product (produk) adalah segala sesuatu yang ditawarkan kepada masyarakat untuk dilihat, dipegang, dibeli atau dikonsumsi. Produk dapat terdiri dari product variety, quality, design, feature, brand name, packaging, sizes, services, warranties, and returns.

2. Price (harga), yaitu sejumlah uang yang konsumen bayar untuk membeli produk atau mengganti hal milik produk. Harga meliputi last price, discount, allowance, payment period, credit terms, and retail price.

3. Place (tempat/distribusi), yaitu berbagai kegiatan perusahaan untuk membuat produk yang dihasilkan/dijual terjangkau dan tersedia bagi pasar sasaran. Tempat meliputi antara lain channels, coverage, assortments, locations, inventory, and transport.

4. Promotion (promosi), yaitu berbagai kegiatan perusahaan untuk mengkomunikasikan dan memperkenalkan produk pada pasar sasaran. Variabel promosi meliputi antara lainsales promotion, advertising, sales force, public relation, and direct marketing.

\section{METODOLOGI PENELITIAN}

Pepsodent adalah pasta gigi yang paling terkenal dan tertua di Indonesia dan hingga saat ini seringkali mendapatkan berbagai penghargaan mengenai produk maupun mengenai pemasarannya.Salah satu penghargaan terbaru yang diterima oleh Pepsodent adalah Word of Mouth (WOM) Marketing Award 2012 untuk produk pasta gigi dari majalah SWA yang diberikan pada 31 Mei 2012 lalu. Dengan adanya penghargaan tersebut membuktikan bahwa Pepsodent sudah sangat melekat pada masyarakat di Indoensia. Perjalanan panjang Pepsodent sejak dahulu menunjukkan semakin kuatnya brand ini berada di 
Indonesia. Dalam pengembangannya di Indonesia, Pepsodent melakukan beberapa strategi pengembangan produk yaitu line extention dan brand extention. Line extention adalah salah satu strategi pengembangan produk dengan memperkenalkan produk baru yang berbeda namun tetap dalam kategori yang sama seperti rasa, bentuk, warna, dan kemasan. Hingga saat ini pasta gigi Pepsodent memiliki sepuluh product line, antara lain Pepsodent Kids, Pepsodent Complate 12, Pepsodent Care, Pepsodent Gigi Susu Strawberry, Pepsodent Gigi Susu Orange, Pepsodent Herbal, Pepsodent Sensitive, Pepsodent Whitening, Pepsodent Gigi Berlubang, dan Pepsodent White Now.

Strategi pengembangan produk yang kedua, brand extention juga dilakukan oleh Pepsodent untuk menarik konsumen serta meningkatkan profit. Brand extention adalah mengembangkan produk dengan kategori baru namun tetap menggunakan merek yang sama. Pepsodent telah memperkenalkan beberapa brand extention di Indonesia, antara lain sikat gigi dan mouthwash. Dari masing-masing brand extention, Pepsodent juga meluncurkan product line extention.

Banyaknya produk serta didukung dengan eksistensinya yang sudah sangat lama di Indonesia merupakan salah satu hal yang mempengaruhi keputusan pembelian pada konsumen. Beberapa hal yang mempengaruhi keputusan pembelian yang dilakukan konsumen secara psikologikal oleh diri sendiri antara lain perception, memory, needs, dan attitudes.

Konsumen tanpa menyadari dalam setiap pengambilan keputusan untuk membeli pasta gigi sangat dipengaruhi oleh keempat hal tersebut. Konsumen memilih produk sesuai dengan kebutuhan mereka masing-masing, apakah untuk gigi sensitif, pemutih gigi, ataupun pasta gigi untuk anak-anak. Keputusan pembelian juga dipengaruhi oleh persepsi serta ingatan akan produk tersebut. Pepsodent memiliki persepsi dan memori yang cukup kuat akan berbagai produknya, hal ini dikarenakan eksistensinya yang cukup lama di Indonesia sehingga melekat pada ingatan masyarakat Indonesia dan menjadi Top of Mind untuk produk pasta gigi.

Keputusan pembelian oleh konsumen tidak hanya dipengaruhi dari diri sendiri, tetapi juga dapat dipengaruhi oleh lingkungan sekitar.Dalam hal ini pengaruh terbesar untuk pembelian produk pasta gigi dilakukan oleh keluarga.Sebagai pelopor pasta gigi di Indonesia, tanpa disadari secara turuntemurun Pepsodent digunakan dalam sebuah keluarga.

Misalkan seorang ayah pada tahun 1950an menggunakan pasta gigi Pepsodent, biasanya seluruh keluarga akan menggunakan pasta gigi yang sama sesuai dengan apa yang tersedia di rumah. Anak dari keluarga tersebut tentu saja akan menjadi dewasa dan menjadi seorang ayah pula, dan akan melakukan hal yang sama seperti yang telah dilakukan oleh ayahnya, sehingga secara turun temurun tanpa disadari keluarga juga memberikan pengaruh dalam keputusan pembelian konsumen.

Peneliti menggunakan jenis penelitian deskriptif-kualitatif, karena menggambarkan karakteristik dari produk, karakteristik konsumen, dan menggambarkan promosi dari produk Pasta gigi Pepsodent serta ingin mendeskripsikan hasil penelitian dengan menggunakan kata-kata tertulis. Dalam penelitian ini, data yang dikumpulkan tidak berbentuk angka, melainkan dalam bentuk kata, kalimat, 
pernyataan, dan konsep. Tujuannya adalah menggambarkan secara terperinci dan relatif akurat mengenai topik yang diangkat dalam penulisan ini.Segala kegiatan pengumpulan data diperoleh dari narasumber yang dipercaya dari pihak PT. Unilever Tbk. Area Bandar Lampung dan konsumen tetap produk Pasta gigi Pepsodent.

Dalam penelitian ini sumber data yang diperoleh adalah:

\section{Data Primer}

Adalah data yang diperoleh secara langsung dari sumbernya. Diamati dan dicatat untuk pertama kalinya. Data tersebut diperoleh melalui:

a. Wawancara

Wawancara dengan pihak PT. Unilever Tbk. Area Bandar Lampung sebagai perusahaan yang meluncurkan produk Pasta Gigi Pepsodent di Bandar Lampung serta konsumen tetap Pasta Gigi Pepsodent.

b. Observasi

Obeservasi meliputi pengamatan langsung yang dilakukan di PT. Unilever Tbk. Area Bandar Lampung, serta melihat pemasaran produk Pasta Gigi Pepsodent yang dilakukan oleh agen dan marketing produk Pasta Gigi Pepsodent yang,kemudian dijadikan data tertulis sebagai rekomendasi isi penelitian ini

c. Quesioner

Pendekatan ini dilakukan dengan memberikan daftar pertanyaan kepada key informan dan informan guna menunjang data yang berhubungan dengan penelitian.

2. Data sekunder

Adalah data yang didapatkan dari buku, serta materi tertulis yang relevan dengan tujuan penelitian. Data sekunder peneliti peroleh melalui pengumpulan data dari pihak PT. Unilever Tbk. Area Bandar Lampung dan melalui studi kepustakaan baik berupa dokumen maupun dokumentasi.

Penentuan Key Informan dan Informan Key informan adalah narasumber kunci atau utama yang paling banyak tahu sesuatu informasi (data) mengenai hal yang diteliti. Sedangkan informan adalah seorang narasumber biasa atau anggota kelompok yang diriset yang diharapkan mempunyai berbagai informasi penting.

Penentuan key informan dan informan, peneliti menggunakan purposive sampling, yaitu pemilihan sampel berdasarkan karakteristik tertentu yang dianggap mempunyai hubungan/sangkut paut dengan karakteristik populasi yang sudah diketahui sebelumnya. (Kriyantono, 2012).

Sehingga penulis memilih key informan berdasarkan karakteristik yang dianggap memiliki informasi yang relevan dengan perumusan masalah penelitian ini. Key informan dalam penelitian ini adalah seorang pimpinan cabang PT. Unilever Tbk. Area Bandar Lampung, Agen dan marketing produk Pepsodent PT. Unilever Tbk. Area Bandar Lampung. Lalu informan dalam penelitian ini adalah konsumen tetap produk Pasta Gigi Pepsodent di Bandar Lampung.

Dalam penelitian ini, teknik analisis data yang penulis lakukan adalah teknik komparatif konstan (Miles dan Huberman, 2014), yaitu :

1. Menempatkan data kedalam kategorikategori yang kemudian kategori tersebut harus dapat diperbandingkan satu dengan yang lainnya.

2. Memperluas kategori tersebut sehingga tidak terjadi tumpang tindih antar kategori

3. Mencari hubungan antar kategori

4. Menyederhanakan dan mengintegrasikan data ke dalam 
struktur teoretid yang koheren (masuk akal, saling bertalian secara logis). Dengan demikian penulis mengkategorikan data menjadi beberapa kategori sesuai dengan konsep bauran pemasaran produk Pasta Gigi Pepsodent, yang kemudian diproses sesuai dengan tahap-tahap diatas.

Pemeriksaaan keabsahan data sangat diperlukan adalah penelitian kualitatif demi kesahihan dan kehandalan serta tingkat kepercayaan data yang terkumpul. Validitas dan realibilitas data perlu diuji melalui teknik keabsahan data atau teknik menguji dan memastikan temuan ( Miles dan Huberman, 2014). Penelitian ini menggunakan teknik menguji dan memastikan temuan melalui memeriksa kerepresentatifan yakni aspek pilihan informan yang mewakili masalah yang diteliti, memeriksa pengaruh peneliti,memberi bobot pada bukti, membuat perbandingan atau pertentangan, membuat replika temuan, mencari penjelasan tandingan, serta teknik terakhir adalah mendapatkan umpan balik dari key informan dan informan.

Teknik umum pengujian keabsahan data dilakukan dengan menggunakan teknik triangulasi. Triangulasi adalah kombinasi beberapa sudut pandang yang sering digunakan meliputi empat hal pokok yakni triangulasi data, triangulasi peneliti, triangulasi teori, dan triangulasi metodologi (Daymon, 2008).

Melalui teknik pemeriksaan ini, penulis menggunakan teknik triangulasi data dan triangulasi teori, di mana data dikumpulkan serta dikaitkan juga dengan teori-teori dari terlaksananya seluruh kegiatan strategi pemasaran produk pepsodent PT. Unilever Tbk. Area Bandar Lampung tersebut, diyakini fakta, data, dan informasi yang didapat dapat dipertanggungjawabkan dan memenuhi persyaratan kesahihan dan keandalan.

Pemeriksaan dan pengecekan dilakukan peneliti pada penelitian ini melalui sumber lain yaitu dengan cara membandingkan data hasil pengamatan dan hasil wawancara dengan key informan. Ini juga termasuk dokumen yang berkaitan dengan studi literatur melalui data sekunder yang diperoleh.

\section{HASIL PENELITIAN DAN PEMBAHASAN}

Unilever Indonesia selain semakin kuat di kancah internasional, Unilever juga semakin kuat di Indonesia. Beberapa brand yang cukup mengakar kuat di Indonesia misalnya Pepsodent, Sariwangi, Molto, Rinso, Ponds, Kecap Bango dan lain-lain. Hampir semua brand yang dimiliki merupakan marca líder en Indonesia.

Salah satu brand yang berhasil mengakar kuat dan sudah lama di Indonesia adalah produk pasta gigi

Pepsodent. Perjalanan panjang Pepsodent menunjukkan semakin kuatnya brand ini. Berbagai upaya yang telah dilaksanakan Unilever berbuah manis. Pepsodent pada awal launching melaksanakan positioning pada gigi lebih putih dan sehat yang selanjutnya disempurnakan sebagai perawatan gigi. Pepsodent kemudian dilengkapi dengan baking soda, setelah sebelumnya sukses dengan Pepsodent Zinc zitrate dan Triclosant. Beberapa tahun sebelum sukses dengan nilai tambahan tersebut, telah sukses dengan fluoride dan kalsium, sehingga terakhir ini fluoride di tambah menjadi Fluoride bicarbonate calcium. Bahkan di perluas dengan Fluoride washmouth. Dalam mengembangkan pemasaran, Pepsodent menggunakan product life cycle strategy.

Di samping mengembangkan produk content sebagai bagian vida de los 
productos cycle strategy, juga terus melakukan inovasi dalam kemasan, rasa, warna, bentuk, ukuran dan merancang produknya sesuai dengan segmentasi pasarnya yakni dewasa dan anak-anak. Selain itu warnanya disesuaikan dengan warna-warna trendi, yakni putih dan hijau baik isi maupun kemasannya.

1. Strategi Pengembangan Pepsodent Dalam pengembangan Pepsodent ini ada beberapa strategi pengembangan produk yang dilakukan Pepsodent yaitu Line Extension, Brand Extension, dan pengembangan multi brand.

a Line extention adalah mengembangkan item produk dengan kategori yang sama dengan menggunakan merek yang sama seperti rasa, bentuk, warna, dan kemasan.

b. Brand extention adalah mengembangkan sebuah produk dengan kategori baru tetapi tetap merek yang sama. Dan ini dilakukan oleh pepsodent sewaktu meluncurkan sikat gigi. Sikat giginya praktis akan berhadapan langsung dengan merek Jordan, Oral-B, Formula, dan sebagainya. Hal ini memungkinan suatu merek akan kehilangan positioning, sehingga ada peluang besar untuk terjadinya Brand dilution, yakni konsumen tidak lagi memiliki preferensi terhadap produk yang dimiliki semula. Ini dapat membuka kesempatan emas bagi pesaingpesaing yang tanggap dan lebih inovatif.

c. Multi brand adalah strategi persaingan dengan menggunakan merek baru namun masih dalam kategori yang sama. Hal ini dengan manis dilakukan oleh pepsodent dengan meluncurkan Close-Up.

Selain ketiga strategi pengembangan produk tersebut, Pepsodent juga melakukan diferensiasi produk yaitu
Pepsodent anak untuk ikut bersaing dalam produk pasta gigi anak.

\section{Kekuatan Pesaing}

Semakin berkembangnya zaman mendorong Pepsodent untuk semakin meningkatkan kualitas produknya dan sedapat mungkin menekan biaya produksi. Selain itu, karena adanya berbagai permintaan konsumen, maka Pepsodent mengembangkan produknya dengan menciptakan berbagai jenis, misalnya pepsodent herbal, pepsodent de triple acción, pepsodent plus whitening, pepsodent complete care.

Sukses pepsodent bukan tidak diikuti oleh pesaing-pesaing, baik lama maupun baru grup orang tua hampir serupa dalam mengikuti gerak-geriknya terutama dengan 2 merek yang dimilikinya yakni Formula, dan sikat giginya.

Kesuksesan Pepsodent tentunya menjadikan pabrikan lain terus mengembangkan produknya. Beberapa pesaing yang dihadapi Pepsodent antara lain Colgate (Palmolive, Amerika), Darlie (Hawley dan Hazel, Hongkong), Oral-B (Oral-B limited, Australia), dan Ciptadent (Lion corporation, Jepang) dan juga Cusson niños, Zwitsal, dan Pigeon untuk pangsa pasar anak - anak. Hal ini tentu saja ada bahannya karena kemungkinan nama mereknya akan kehilangan positioning, sehingga peluang terjadinya Brand dilution yakni konsumen tidak lagi memiliki prefensi terhadap produk yang dimiliki semula akan terbuka. Dan ini kesempatan emas juga bagi pesaing-pesaing yang tanggap dan lebih inovatif.

\section{Produk Life Cycle}

Daur kehidupan produk, yang diperkenalkan tahun 1950, mencoba menganalisa suatu produk berdasarkan perubahan yang terjadi pada tingkat penjualannya. Prinsipnya analisa ini mengatakan bahwa suatu produk akan 
melalui suatu siklus kehidupan (ciclo de vida) seperti hanya manusia yaitu kelahiran, pertumbuhan, dewasa, dan akhirnya masa tua (meninggal).

Pepsodent awal tahun 1980-an hanya memiliki tema positioning pada gigi lebih putih dan sehat dengan kalimat penyempurnaan "perawatan kesehatan gigi", maka tahun belakangan ini menambah nilainya menjadi "penguat gigi, sehingga gigi tetap utuh dalam usia senja" bersamaan dengan inovasi yang dilakukan terus menerus, semakin memperkokoh kedudukannya, bukan lagi sebagai pasta gigi semata, tetapi menjadi penyangga kesehatan dan penguat ketahanan gigi.

Setiap produk untuk tetap bertahan tergantung seberapa inovatif sebuah produk mengikutivida del producto cycle (PLC) yang harus diperbaharui memenuhi selera konsumen yang berubah, berkembang dan tumbuh bersama dengan pola-pola perilaku dan tuntutan masyarakat. Pepsodent menjalankan PLC secara konsisten. Namun PLC yang menjadi kerangka kebijaksanaannya tentu saja sulit berhasil apabila tidak ditunjang oleh komunikasi pemasaran yang kreatif dan mengkomunikasikannya terus menerus dan konsisten melalui berbagi de comunicación. Tapi pepsodent menjalankannya dengan baik.Karena itu, barangkali menarik, menilik, dan menyimpulkan produk dan brand strategy yang dikembangkannya.

.4. Strategi Pemasaran Dalam Persaingan Bisnis

Pendesainan produk yang dilakukan Unilever terhadap Pepsodent, terutama ditujukan untuk memenuhi kepuasan konsumen (customer satisfaction). Selain itu, sebagai produk yang sudah dikenal masyarakat pada umumnya, Pepsodent juga telah memenuhi standar kesehatan karena terdapat label halal pada kemasannya. Jadi masyarakat yakin akan produk ini tidak membahayakan kesehatan dapat digunakan oleh semua kalangan masyarakat.

Degree of Newness dari produk Pada dasarnya produk pasta gigi diciptakan untuk

membersihkan gigi dan merawatnya agar tetap sehat. Namun, pasta gigi yang hanya berfungsi seperti itu sudah jarang ditemukan, karena saat ini produk pasta gigi telah hadir dalam berbagai versi tidak hanya untuk membersihkan gigi tetapi bisa sekaligus membuat gigi tampak lebih putih, wangi dan berbagai keuntungan lain yang ditawarkan tiap produk.

Demikian halnya yang terjadi pada

Pepsodent. Semula Pepsodent diciptakan hanya untuk merawat dan menguatkan gigi. Kemudian Pepsodent memberi nilai tambah pada produknya yaitu dilengkapi dengan Fluoride dan Kalsium. Setelah beberapa tahun sukses dengan terobosan barunya, Pepsodent kembali membuat inovasi yaitu yang sebelumnya Fluoride ditambah menjadi Fluoride bicarbonate calcium, bahkan diperluas dengan Fluoride washmouth. Dengan semua inovasi tersebut ternyata Pepsodent belum puas, selang beberapa tahun kemudian Pepsodent hadir dengan Pepsodent Zinc zitrate dan Triclosant, lalu disusul dengan baking soda. Kemasannya dibuat dari plastik lentur dan tutup yang lebih adaptif setelah sebelumnya dari aluminium dan tutup lepas. Rasanya dibagi sesuai dengan cita rasa buah-buahan atau rasa mint. Selain itu, warnanya disesuaikan dengan warna-warna trendi, yakni putih dan hijau baik isi maupun kemasannya. Ukurannya diatur dari kecil, sedang, hingga besar, sehingga lebih praktis dan cukup mempengaruhi harga.

Beberapa tahun terakhir ini perkembangan dunia bisnis sangatlah cepat dan membuat pihak-pihak yang terlibat didalamnya harus bekerja keras agar keberadaannya tetap diakui oleh 
pelanggan mereka. Jika dahulu pelanggan membutuhkan sesuatu untuk pemutih gigi, mereka akan dapat dengan cepat mendapatkannya. Hal ini terjadi karena pasta gigi yang ada ditujukan untuk semua orang (semua segmen pasar). Saat ini jika kita membutuhkan pasta gigi, akan terdapat banyak pilihan yang ditawarkan antara lain Pepsodent, Close-Up, Ciptadent, dan lain-lain dan ini akan membuat kesulitan tersendiri bagi pelanggan untuk memilih. Semakin beragamnya jenis dan macam pasta gigi (dan produk lainnya) menggambarkan semakin ketatnya persaingan dalam dunia bisnis. Bervariasinya merek dan jenis produk menunjukkan bahwa perusahaan tidak dapat hanya berdiam diri dalam melakukan bisnisnya.Perusahaan harus mulai berpikir untuk mengalahkan a sus rivales. Hanya perusahaan yang betulbetul kuat yang akan memenangkan persaingan. Dalam usahannya menuju perusahaan yang kuat, para pengambil keputusan (Chief Executive Officers) didalam perusahaan Unilever diwajibkan untuk merubah cara berpikir mereka.

Pendesainan produk yang dilakukan Unilever terhadap Pepsodent terutama ditujukan untuk memenuhi kebutuhan konsumen. Pepsodent membuat segmentasi pasar terbagi dua yakni dewasa dan anak-anak dan telah memenuhi standar kesehatan karena terdapat label halal pada kemasannya. Untuk masalah yang terkait dengan degree of newness dari pendesainan suatu produk, Pepsodent telah melakukan banyak inovasi pada produknya dengan menambahkan zatzat tertentu ke dalam produknya, melakukan inovasi kemasan, rasa, bentuk dan ukuran, tidak hanya itu, Pepsodent juga berhasil melakukan de línea extention, brand extention dan multibrand extention, sehingga pasta gigi Pepsodent tetap menjadi produk andalan yang dimiliki Unilever sampai saat ini

Pepsodent adalah pasta gigi yang paling terkenal dan tertua di Indonesia, sejak awal keberadaannya selalu memberikan lebih dari sekedar kemanjuran dasar. Pepsodent adalah pasta gigi pertama di Indonesia yang kembali meluncurkan pasta gigi berflorida pada tahun 1980-an dan satu-satunya pasta gigi di Indonesia yang secara aktif mendidik dan mempromosikan kebiasaan menyikat gigi secara benar melalui program sekolah dan layanan pemeriksaan gigi gratis. Sejak itu Pepsodent telah melengkapi jajaran produknya mulai dari pembersihan dasar hingga pasta gigi dengan manfaat lengkap.

Pepsodent telah menjadi market leader dan menguasai pangsa pasar untuk produk pasta gigi.Saat ini produk Pepsodent memiliki bermacam macam varian yaitu klasik, herbal, whitening, complate care dan anak anak. Selama brand mix-nya kuat akses ke konsumen menjadi makin mudah. banyak masyarakat Indonesia yang belum mengerti cara menyikat gigi dengan benar. Di situlah Pepsodent menangkap peluang untuk menyosialisasi sekaligus memberi pengetahuan mengenai kesehatan gigi. Tujuannya, meningkatkan kesehatan gigi dan mulut bangsa Indonesia.

Pada tahun 2006, Pepsodent telah meluncurkan dan meluncurkan kembali varian lengkap Pepsodent Barunya:

a. Pepsodent Complete 12, yang menawarkan manfaat yang lengkap dengan harga terjangkau. Menawarkan manfaat yang lebih banyak kepada para konsumennya sebagai bagian dari upayanya untuk mencapai misinya.

b. Pepsodent Sensitive, yang menawarkan bahan aktif yang menembus gigi untuk membebaskan 
rasa sakit akibat syaraf yang sensitif di dalam gigi dan gusi.

c. Pepsodent Fighter Toothbrush.

Dengan semua inovasi baru ini, Pepsodent mencakup seluruh jangkauan perawatan kesehatan mulut para konsumennya.

\section{Segmenting}

Proses segmentasi berbeda dari positioning pasar (menerapkan strategi bauran pemasaran yang tepat untuk setiap segmen). Tujuannya adalah untuk mengidentifikasi kelompok pelanggan yang sama dan pelanggan potensial, untuk memprioritaskan kelompok, untuk memahami perilaku mereka dan untuk merespon strategi pemasaran yang tepat dalam memenuhi preferensi yang berbeda dari setiap segmen yang dipilih. Peningkatan segmentasi dapat menyebabkan efektivitas pemasaran meningkat secara signifikan.

Segmentasi pasar mengacu pada proses pembentukan kelompok kecil dalam pasar yang besar, sehingga dapat menentukan konsumen mana yang memiliki keinginan dan kebutuhan yang sama.

Segmenting pada Pepsodent sudah sangat luas. Sehingga dengan begitu nama Pepsodent dapat menjadi pilihan pertama yang melintas dibenak hampir seluruh masyarakat Indonesia. Target pasar produk Pepsodent ini adalah konsumen semua usia, baik mulai anakanak sampai dewasa. Pepsodent mengelompokkan produknya berdasarkan usia. Untuk anak-anak disesuaikan dengan rasa yang biasanya disukai oleh anak-anak dan mengandung mint yang lebih sedikit. Untuk produk anak-anak antara lain: Kids, Gigi Susu Strawberry, dan Gigi Susu Orange. Untuk dewasa antara lain: Complete 12, Complete Care, Herbal, Sensitive, Whitening, White, Dan Pepsodent White Now. Untuk dewasa setiap jenis produk memiliki fungsi yang berbeda-beda ini menunjukkan bahwa Pepsodent ingin memenuhi kebutuhan konsumen di setiap masalah gigi yang berbeda-beda.Pepsodent juga dapat digunakan untuk semua jenis kelamin.

Pepsodent memasarkan produknya melalui media elektronik dan media cetak yang menarik, dengan media elektronik yaitu melalui media periklanan.Pepsodent juga memasarkan produknya melalui media-media cetak seperti melalui bilboard atau majalah. selain itu Pepsodent juga memperkenalkan produknya melalui event-event yang mereka buat, salah satu contohnya yaitu "Senyum Pepsodent", melalui event ini Pepsodent memperkenalkan produknya secara langsung dengan memberikan pengetahuan tentang manfaat bersikat gigi, cara sikat gigi dengan benar. Melalui event ini lah Pepsodent dapat merebut hati masyarakat agar masyarakat menggunakan produknya, dengan event ini juga Pepsodent mengenalkan produknya agar lebih dikenal di masyarakat dan di pasaran, melalui event ini juga Pepsodent memberikan sikat gigi dan pasta gigi gratis kepada para pesertanya, ini juga salah satu cara untuk merebut hati masyarakat.

\section{Targeting}

Targeting adalah persoalan bagaimana memilih, menyeleksi, dan menjangkau pasar. Targeting atau menetapkan target pasar merupakan tahap selanjutnya dari analisis segmentasi. Produk dari targeting adalah target market (pasar sasaran), yaitu satu atau beberapa segmen pasar yang akan menjadi fokus kegiatan-kegiatan pemasaran. Kadangkadang targeting juga disebut selecting karena marketer harus menyeleksi. Targeting merupakan proses mengevaluasi segmen pasar dan memusatkan upaya pemasaran pada negara, kawasan atau kelompok orang yang memiliki potensi signifikan untuk 
beraksi secara positif terhadap stimulus pemasaran dari perusahaan. Proses targeting mencerminkan kenyataan bahwa perusahaan harus mengidentifikasi pelanggan yang dapat diakses dan dilayani secara efektif dan efisien.

Targeting pada Pepsodent adalah dua digit angka pertumbuhan meskipun timbul persaingan ketat di kategori utama. Home dan Personal Care secara keseluruhan tumbuh 11,2\%. Kategori produk kami termasuk sukses dalam penjualannya. Marjin laba usaha masih memuaskan yang mencapai $20,3 \%$ dari penjualan. Pada dasarnya laba bersih sedikit dibawah tahun-tahun sebelumnya disebabkan oleh marjin yang lebih rendah dan adanya selisih nilai tukar mata uang asing (keuntungan Rp 8 miliar di tahun 2005 dan Rp 34 miliar di tahun 2004 dengan pergerakan sebesar Rp 26 miliar). Tahun 2012 laba per saham mencapai Rp 189 per saham.

Pepsodent memiliki komitmen untuk terus menerus mengadakan perbaikan dalam pengelolaan dampak lingkungan dan mendukung sasaran jangka panjang untuk mengembangkan suatu bisnis yang berdaya tahan. Pepsodent akan bekerja sama dalam kemitraan dengan pihak lain untuk menggalakkan kepedulian lingkungan, meningkatkan pemahaman akan masalah lingkungan dan menyebarluaskan budaya karya yang baik. Pepsodent tidak menerima ataupun memberi, entah secara langsung dan tidak langsung, suapan atau keuntungan lainnya yang tidak pantas demi keuntungan bisnis atau finansial. Tidak satu pun karyawan kami yang boleh menawarkan, memberi ataupun menerima hadiah atau pembayaran yang merupakan, atau dapat diartikan sebagai sarana suap. Setiap tuntutan, atau penawaran suap harus ditolak langsung dan dilaporkan kepada manajemen. Catatan akuntansi dan dokumen pendukungnya harus secara tepat menjelaskan dan mencerminkan kondisi transaksinya. Tidak ada transaksi dana atau aset yang disembunyikan atau tidak.

\section{Positioning}

Salah satu brand yang berhasil mengakar kuat dan sudah lama di Indonesia adalah produk pasta gigi Pepsodent.Perjalanan panjang Pepsodent menunjukkan semakin kuatnya brand ini. Berbagai upaya yang telah dilaksanakan Unilever berbuah manis. Pepsodent pada awal launching melaksanakan positioning pada gigi lebih putih dan sehat yang selanjutnya disempurnakan sebagai perawatan gigi. Positioning adalah suatu usaha melekatkan persepsi atas suatu produk pada sekelompok pasar atau segmen tertentu agar produk itu mampu dianggap lebih dan cocok dengan keinginan dan kebutuhan segment tersebut, semua dalam rangka membangun persepsi positif. Sehingga pada segmen yang berbeda memerlukan strategi positioning yang berbeda, atau dengan memperluas, memperbaiki, menambah atas strategi positioning yang telah ada. Strategi positioning sebagai dasar dari strategi pemasaran dan menjadi dasar yang populer dari pengembangan strategi kreatif. Gagasan umum dari positioning adalah menempatkan sebuah produk untuk mendapatkan posisi yang baik dalam benak konsumen. Merek yang telah memiliki posisi mapan dalam benak akan menjadi faktor pengaruh yang kuat pada saat konsumen memerlukan solusi.

Pepsodent yang dulu juga membangun positioning statement "Gigi Putih" saat ini telah berhasil melakukan repositioning dengan "Perlindungan Gusi" dan "Perlindungan Gigi Berlubang". Perubahan ini bukan semata-mata kata-kata yang diubah, namun produsen telah memikirkan 
perubahan kuantitatif target pasar dan segmen pasar yang dibidik, tentu ketika seseorang mencapai usia tua dengan gigi berlubang sangatlah tidak nyaman, sehingga Pepsodent menjadi jawabannya.

\section{Diferentiation}

Diferensiasi ada untuk menciptakan sebuah perbedaan yang bertujuan memberikan nilai lebih kepada para konsumen. Dengan begitu sebuah produk akan lebih mudah dikenali dan memberikan daya tarik tersendiri bagi para konsumen. Sehingga mereka lebih memilih produk kita, dibandingkan produk lainnya yang ada dipasaran. Dengan diferensiasi produk membuat bagaimana perusahaan dapat menciptakan produk unik yang memberikan tingkat keuntungan di atas rata-rata yang mampu diraih oleh industri melalui kombinasi manusia, lingkungan dan proses.

Keuntungan yang akan diperoleh para pelaku pasar dari strategi diferensiasi produk:

a. Produk lebih mudah diingat para konsumen

b. Produk lebih unggul dibandingkan dengan produk lainya. Karena dengan produk yang unggul akan memudahkannya dalam membangun loyalitas konsumen.

c. Harga jual produk lebih tinggi. Sebuah produk yang memiliki keunikan khusus, biasanya akan diburu konsumen dengan harga berapapun.

d. Mengatasi masalah kejenuhan pasar adanya diferensiasi produk dapat membantu para pelaku pasar ketika konsumen sudah mulai jenuh dengan produk yang biasa ditawarkannya

e. Membantu terciptanya image produk pada produk Pepsodent diferensiasi yang utama adalah : a. Pepsodent adalah merek terkemuka di sebagian besar negara Asia dengan Indonesia dan India sebagai pasar terbesar.

b. Pada tahun 2005 Pepsodent merupakan satu-satunya merek pasta gigi yang diakui oleh FDI, Federasi Gigi Dunia, di samping asosiasi dokter gigi di dalam negeri.

c. Pepsodent anak ikut bersaing dalam produk Pasta gigi anak.

d. Pepsodent, mengunakan diferensiasi kontent dalam meluncukan varian baru pasta gigi dari Triple action sampai Herbal Cooling dan juga Pepsodent mengeluarkan sikat gigi yang inovatif. fokus diferensiasi Pepsodent pada konten yaitu bagaimana menghasilkan produk inovatif yang terdepan.

\section{Communication Mix}

Metode advertising/periklanan dalam proses mengkomunkasikan produk Pepsodent ke konsumen juga sangat signifikan. Jika kita nonton TV, maka pepsodent akan familiar dengan kebiasaan menyikat gigi turun-temurun. Mulai anak-anak, gadis, berankak menjadi ibu dan menjadi nenek-nenek. Merode lain adalah melakukan perikalanan yang melakukan kebiasaan menyikat gigi sebelum tidur.

Konsep sales promotion yang digunakan oleh Pepsodent untuk mempengaruhi kosumennya adalah menggukan bahasa promosi tentang pengetahuan yang mendalam mengenai produk Pepsodent. Penerapan strategi komunikasi dan promosi yang menarik ini akan mendorong konsumen untuk menggunakan Pepsodent. Promosi dan komunikasi yang menarik tentunya Pepsodent akan meningkatkan brand awareness merek tersebut. Brand loyality pun selalu diawali dari brand awareness yang baik yang akan membawa seseorang pada tahap 
"mencoba produk". Setelah konsumen percaya bahwa produk yang digunakan sesuai dengan kebutuhannya maka akan tercipta "repeat purchase" dengan memberikan lebih dari yang diharapakan, repeat purchase akan berubah menjadi loyality. disamping itu Pepsodent juga selalu memformulasikan brand activation yang tepat untuk menjawab tantangan dan kebutuhan disetiap level.

Event yang dilakukan oleh Pepsodent juga cukup gencar, beberapa kegiatan kampanye below the line. Pepsodent yang akrab terdengar di sekolah dengan metode pemeriksaan gigi gratis. Aktivitas nyata program ini adalah menyikat gigi bersama yang dilakukan oleh anak-anak Sekolah Dasar. Program ini juga telah menjangkau 3,2 juta anak berusia dibawah 12 tahun.

Public relation yang diluncurkan oleh Pepsodent melakukan hubungan baik dengan para konsumennya dengan cara memberikan kualitas prima untuk produk Pepsodent. Hal lain seperti Direct marketing adalah Penggunaan teknologi internet. Penggunaan teknologi ini juga menjadi concern dalam strategi pemasaran yang dilakukan oleh Pepsodent. Internet dan mobile merupakan media yang memiliki potensi untuk dikembangkan dalam rangka strategi pemasarannya.

\section{Target Audience}

Pepsodent yang diluncurkan sejak tahun 1951 memposisikan diri sebagai produk kesehatan gigi dan mulut. Segmen yang dituju berasal dari kalangan dewasa hingga anak-anak. Harganya relatif bisa terjangkau. Pada tahun 2009 Pepsodent menargetkan pertumbuhan yang positif dengan melakukan beragam aktifitas komunikasi dan promosi menarik. Pepsodent juga mengembangkan website yang memberikan informasi tentang produk dan kegiatan yang dilakukan oleh Pepsodent. Tidak hanya itu tetapi website Pepsodent juga berkerja sama dengan situs-situs lain yang berhubungan dengan kesehatan gigi dan mulut.

7. Evaluasi atas Media Utama

Pelaksanaan pesan sangat menentukan dalam produk yang sangat mirip, dalam beriklan los medios de comunicación televisi Pepsodent menyiapkan pernyataan berupa strategI yang menggambarkan tujuan, isi, dukungan dan nada dari iklan yang diinginkan. Semua pesan dapat disajikan dalam gaya pelaksanaan yang berbeda, yakni penggambaran kebiasaaan menyikat gigi yang turun temurun, mulai sejak masih anak gadis, kemudian beranjak menjadi ibu, dan akhirnya menjadi nenek-nenek. Dalam hal ini Pepsodent menerapkan semua jenis advertising objective berasal dari target pasar, market positioning dan bauran pemasaran. Pepsodent menerapkan ke empat jenis advertising objective secara bersamaan melalui 3 medios utamanya yaitu, televisi, program below the line dimana Pepsodent melakukan program sekolah Pepsodent dan pemeriksan gigi gratis, program menyikat gigi yang dilakukan anak-anak SD telah menjangkau 3,2 juta anak, dan media yang terakhir adalah media website Pepsodent: Kegiatan periklanan pada ketiga media mencakup klasifikasi advertising objective yaitu:

a.Informative advertising untuk menciptakan awareness (new products, features, price dan services), melalui produkproduk variannya Pepsodent merasa perlu terus menginformasikan untuk menciptakan awareness target marketnya.

b.Persuasive advertising untuk menciptakan liking, preference, conviction, and purchase. Kadang 
gunakan comparative adv, (dalam iklan dimunculkan perbandingan kekuatan gigi jika menggunakan Pepsodent).

c. Reminder advertising untuk menstimulir repeat purchase.

d.Reinforcement advertising untuk meyakinkan

bahwa pilihannya benar.

\section{KESIMPULAN DAN SARAN}

\section{Kesimpulan}

Dari hasil analisis penelitian dan pada pembahasan ini, maka kesimpulanya adalah sebagai berikut :

1. Pepsodent memiliki sepuluh product line, antara lain Pepsodent Kids, Pepsodent Complate 12, Pepsodent Care, Pepsodent Gigi Susu Strawberry, Pepsodent Gigi Susu Orange, Pepsodent Herbal, Pepsodent Sensitive, Pepsodent Whitening, Pepsodent Gigi Berlubang, dan Pepsodent White Now.

2. Harga produk pasta gigi Pepsodent untuk area Bandar Lampung sangat terjangkau oleh masyarakat baik itu Pepsodent Kids, Pepsodent Complate 12, Pepsodent Care, Pepsodent Gigi Susu Strawberry, Pepsodent Gigi Susu Orange, Pepsodent Herbal, Pepsodent Sensitive, Pepsodent Whitening, Pepsodent Gigi Berlubang, dan Pepsodent White Now.

3. Strategi pengembangan produk dengan memperkenalkan produk baru yang berbeda namun tetap dalam kategori yang sama seperti rasa, bentuk, warna, dan kemasan. Strategi pengembangan produk yang kedua, brand extention juga dilakukan oleh Pepsodent untuk menarik konsumen serta meningkatkan profit. Brand extention adalah mengembangkan produk dengan kategori baru namun tetap menggunakan merek yang sama. Pepsodent telah memperkenalkan beberapa brand extention di Indonesia, antara lain sikat gigi dan mouthwash. Dari masing-masing brand extention, Pepsodent juga $m$ an product line extention.

\section{Saran}

1. Lebih meningkatkan kegiatan promosi produk pasta gigi Pepsodent, agar konsumen lebih mengetahui lebih banyak tentang jenis produk yang diinginkan.

2. Lebih memahami keinginan konsumen dalam memilih sebuah produk melalui survey pasar.

\section{DAFTAR PUSTAKA}

Alma, Buchari, (2013): Manajemen Pemasaran dan Pemasaran Jasa.Alfabeta, Bandung.

American Marketing Association (AMA) yang dikutip oleh Philip Kotler dan Keller Kevin Lane yang diterjemahkan oleh Bob Sabran.2009.

Assauri, Prof. Dr. Sofjan, MBA. 2004. Manajemen Pemasaran. PT. Raja Grafindo Persada, Jakarta.

Basu Swastha, dan T. Hani Handoko, 2008, Manajemen Pemasaran, Analisa Perilaku Konsumen, edisi pertama, cetakan keempat, Penerbit : BPFE, Yogyakarta

Cannon, Perreault dan McCarthy. 2009. Pemasaran Dasar Pendekatan Manajerial Global Buku 2 Edisi 16. Jakarta: Salemba Empat.

Daymon, Christine. 2008. MetodeMetode Riset Kualitatif dalam Public Relations dan Marketing. Bentang. Yogyakarta. 
Kotler, Philip \& Armstrong, G. 2012. Principle of Marketing (Edisi 14). Boston: Pearson Education.

Kotler, Philip and Kevin Lane Keller, (2012): Marketing Management New Jersey: Pearson Pretice Hall, Inc.

Kriyantono, Rahmat. 2012. Teknik Praktis Riset Komunikasi. Jakarta : PT. Kencana Perdana.

Miles,M.B, Huberman,A.M, dan Saldana,J. 2014. Qualitative Data Analysis, A Methods Sourcebook, Edition 3. USA: Sage Publications. Terjemahan Tjetjep Rohindi Rohidi, UI-Press.

Stanton, William J. 2012. Prinsip pemasaran, alih bahasa : Yohanes Lamarto Penerbit Erlangga, Jakarta.

Stephanie \& K. Marrus. (2002). Desain Penelitian Manajemen Strategik. Jakarta: Rajawali Press.

$\underline{\text { www.swa.co.id }}$

www.tanyapepsodent.com

$\underline{\text { www.unilever.co.id }}$ 